\title{
Advances in blood-based protein biomarkers for Alzheimer's disease
}

\author{
Lorraine Fuhrmann Clark and Thomas Kodadek*
}

\begin{abstract}
Alzheimer's disease (AD) is a neurodegenerative disorder that accounts for the majority of dementia cases. While research over the past decades has made advances into understanding disease pathology, definite AD diagnosis currently relies on confirmation by autopsy. The anticipated dramatic rise in affected individuals over the next decades necessitates the development of diagnostic tests applicable to living individuals, which depends on identification of disease biomarkers. Diagnostics based on blood protein biomarkers are particularly desired since these would allow for economical, rapid and non-invasive analysis of individual biomarker profiles. Research is actively ongoing in this field and has led to the identification of autoantibodies and various proteins in the blood that may represent a disease-specific blood signature of AD. This review provides an overview on the progress in the field of identification of AD-specific blood protein biomarkers.
\end{abstract}

\section{Introduction}

Alzheimer's disease (AD) is a neurodegenerative disorder characterized by progressive cognitive decline that generally afflicts people over the age of 65 , although a form of the disease known as familial early-onset AD can affect people as early as in their forties. The pathological changes associated with the disease are thought to begin decades prior to the emergence of clinical symptoms [1]. $\mathrm{AD}$ is the most common form of dementia today, with an estimated 5 million people currently affected in the United States and an estimated worldwide prevalence of 34 million [2,3]. The increasing growth of the aging population and the associated increase in $A D$ cases is predicted to place a heavy financial toll on society as the

*Correspondence: Kodadek@scripps.edu

Departments of Chemistry and Cancer Biology, The Scripps Research Institute, 130 Scripps Way, Jupiter, FL 33458, USA annual cost is projected to reach $\$ 1$ trillion by 2050 in the United States alone [4].

A critical unmet medical need in this area is an accurate and sensitive test for very early-onset $A D$, preferably at the presymptomatic stage. The immediate application will be to better identify candidates for clinical trials of potential AD therapeutics. There is general agreement that a major problem with the almost uniformly disappointing clinical trials conducted to date for potential AD therapeutics is that they employed patients with moderate to advanced disease [5]. Even an effective agent for blocking pathophysiological events in $\mathrm{AD}$ is highly likely to be, at best, marginally effective once most of the damage is already done. If an effective drug does become available, then a screening test for oncoming AD will become of critical importance and will command a huge market. Given this goal of developing a practical, economical, high-volume test for very early $\mathrm{AD}$, the discovery of simple-to-measure blood biomarkers for the disease has been a topic of great interest. This review summarizes recent progress in this field with a focus on protein, rather than nucleic acid, biomarkers.

Beta-amyloid as an Alzheimer's disease biomarker

The presence of amyloid beta $(A \beta)$ plaques and neurofibrillary tangles composed of hyperphosphorylated tau protein present in brains of affected individuals comprise the hallmark pathology of $\mathrm{AD}[6]$. The $\mathrm{A} \beta$ peptide is generated by cleavage of the amyloid precursor protein yielding fragments varying from 37 to 42 amino acids in length, of which the 42 -amino-acid version in particular is associated with $\mathrm{AD}$ due to its tendency to form plaques [7].

Transport of $A \beta$ into the brain is promoted by the receptor for advanced glycation products expressed on the endothelium [8]. Deposition of $A \beta$ in the brain is believed to be the primary event in $\mathrm{AD}$, initiating a cascade of pathological changes including formation of tau neurofibrillary tangles [9]. Inside the brain, $A \beta$ is capable of forming a high-affinity complex with the neuron-associated $\alpha_{7}$-nicotinic acetylcholine receptor, leading to its subsequent endocytosis. The resulting increase in neuronal $A \beta$ burden eventually causes cell 
lysis and ensuing extracellular accumulation of $A \beta$ [10-13].

In addition to the nicotinic acetylcholine receptors, $A \beta$ binds to a variety of other receptors, including neurotransmitter receptors, toll-like receptors, NOD-like receptors, formyl peptide receptors, scavenger receptors, complement receptors, pentraxins as well as the receptor for advanced glycation products expressed on astrocytes, microglia and neurons $[14,15]$. These interactions induce the production of proinflammatory molecules through signaling pathways, most of which involve activation of microglia, and eventually culminate in neuronal death [8,14-16].

The central role of $A \beta$ in $A D$ suggested that it would be a candidate disease biomarker and, according to a recent review, about 26 investigations have been performed to evaluate both $A \beta 40$ and $A \beta 42$ as useful diagnostic markers [2]. However, the results of these studies are contradictory because some report an association between a decline in plasma $A \beta 40$ and $A \beta 42$ levels as well as in the $A \beta 42 / A \beta 40$ ratio with development of $A D$, while other studies found no correlation between plasma $A \beta$ and $\mathrm{AD}$. The lack of general consensus with regards to plasma $A \beta$ and $A D$ risk currently prevents its use as a diagnostic marker for AD. Further research into this area as well as standardization of research techniques (such as sample collection techniques and methods used for categorization of study participants) is required. Changes in $A \beta$ levels in the cerebrospinal fluid have also been linked to $\mathrm{AD}$ risk, and it is generally accepted that a decline in cerebrospinal fluid $A \beta$ is a reflection of increasing plaque load in the brain [17]. The invasiveness of the lumbar puncture procedure, however, places a limitation on its applicability to widespread monitoring of at-risk populations. Other novel plasma and serum AD biomarkers are being actively investigated and are discussed in the following sections.

\section{Clusterin and its role in Alzheimer's disease}

Clusterin, also known as apolipoprotein J, is a heterodimeric glycoprotein expressed in the majority of mammalian tissues [18]. The predominant clusterin isoform is a 75 to $80 \mathrm{kDa}$ secretory protein but smaller nuclear and cytoplasmic versions exist [19]. The exact physiological role of clusterin remains uncertain but it has been implicated in a variety of processes including apoptosis, lipid transport and complement regulation, and it also functions as a molecular chaperone [20]. As a chaperone, clusterin is involved in both promotion and prevention of $A \beta$ aggregation, depending on the clusterin to $A \beta$ ratio [21]. Clusterin is a stress-induced protein that is increasingly expressed during certain disease states, including $\mathrm{AD}$, and as a response to neuronal injury and degeneration $[18,22]$. Noteworthy is the fact that clusterin is found in amyloid plaques along with apolipoprotein E, and variants within both the CLU gene and the $A P O E$ gene have been identified as susceptibility loci for $\mathrm{AD}$ in genome-wide association studies [23-26].

Recent investigations independently discovered a pathological role of plasma clusterin levels with regard to AD. One study applied mass spectrometry-based proteomics in combination with neuroimaging to a cohort consisting of subjects with $\mathrm{AD}$ or mild-cognitive impairment and control subjects in order to identify plasma components associated with $\mathrm{AD}$ [27]. The results revealed a relationship between increased plasma clusterin levels and atrophy of the entorhinal cortex, Mini-Mental State Examination score, and accelerated cognitive decline. Additionally, elevated plasma clusterin concentrations were discovered 10 years prior to $A \beta$ depositions in the brains of normal older subjects.

Another study involving a population-based cohort confirmed the association between increased plasma clusterin levels with prevalence and severity of AD [28]. However, no correlation between plasma clusterin concentration and the risk of incident $\mathrm{AD}$ was found. This raises the question of whether increased plasma clusterin levels are a sign of impending $\mathrm{AD}$ or a response to pathological changes that accompany AD. Furthermore, the latter study demonstrated that clusterin could not distinguish between AD and vascular as well as all-cause dementia. Clusterin may therefore be not useful as a standalone AD diagnostic marker.

The water was further muddied by a very recent paper that attempted to utilize clusterin as a marker in a study of 171 controls, 127 patients with AD, 82 patients with other dementias and 30 patients with depression [29]. These authors found similar levels of serum clusterin in all of these groups and concluded that the level of plasma clusterin is not of diagnostic value in $\mathrm{AD}$.

Why there is such a great discrepancy between these studies is not clear, but the clusterin literature certainly emphasizes the importance of confirmation of potential serum biomarkers in large, blinded studies conducted by workers at different institutions with different samples.

\section{Discovery of panels of plasma protein biomarkers}

Serum/plasma proteomics has been brought to bear on many diseases, including $\mathrm{AD}$. This approach employs some type of massively parallel analytical technique to measure the levels of hundreds to thousands of circulating proteins in case and control sample populations [30]. Proteins that are consistently highly upregulated or downregulated in the case population relative to the control samples are then analyzed further as possible biomarkers.

An example of this approach was a 2007 study by WyssCoray and coworkers using a filter-based arrayed ELISA to measure the levels of 120 known signaling proteins in 
the plasma of $259 \mathrm{AD}$ and age-matched control samples [31]. A statistical algorithm was employed to choose 18 of these proteins as a potential marker set for AD. Note that this must have meant that the level of any single protein or even a combination of a small number of proteins (three to five proteins) did not have had sufficient predictive power in the initial dataset to merit further investigation. Subsequent analysis of a modest number of patients using this 18-protein ELISA panel provided highly promising results, with diagnostic specificity and selectivity approaching 90\%, including correct identification of samples from patients that would later develop $\mathrm{AD}$ but who were presymptomatic at the time of sampling.

A larger study published recently employed 600 samples from two independent cohorts collected at University of Pennsylvania and the Washington University School of Medicine [32]. The study analyzed levels of 190 plasma proteins and peptides. As part of this study, the 18-marker panel mentioned above was evaluated and found to have a diagnostic accuracy of $61 \%$, another example of strikingly different results obtained by different laboratories in different cohorts. Two other independent studies also failed to reproduce the results from the same study [33,34]. The present study identified 17 analytes that were associated with early AD. Four of these analytes - apolipoprotein E, B-type natriuretic peptide, C-reactive protein and pancreatic polypeptide were also found to be altered in a third cohort of 566 patients obtained from the Alzheimer's Disease Neuroimaging Initiative collection. The authors concluded that these four plasma markers, perhaps in concert with cerebrospinal fluid markers, are good candidates for further analysis in a prospective study. This collection of serum proteins would appear to be the most promising to date for the diagnosis of early $\mathrm{AD}$, and certainly so far the most thoroughly vetted.

\section{Mining the immune system for Alzheimer's disease biomarkers}

$\mathrm{AD}$ is not generally thought of as an immune-related condition. However, recent data are beginning to change this point of view. Preliminary work has even suggested that AD-specific autoantibodies might serve as useful diagnostic markers for the disease.

Genome-wide association studies performed over the last few years appear to support the importance of the immune system in AD. A variant of the CR1 gene, which encodes the complement component $(3 \mathrm{~b} / 4 \mathrm{~b})$ receptor 1 , was found to be associated with the risk of late-onset $\mathrm{AD}$ in one of the studies that also identified a susceptibility locus on the CLU gene [25]. Additionally, two independent studies recently identified an association between the same SNP within the TREM2 gene and the risk of developing $\mathrm{AD}$. This gene codes for the triggering receptor expressed on myeloid cells-2, a transmembrane protein found on immature dendritic cells, osteoclasts, and microglia. In microglia, receptor expressed on myeloid cells-2 receptors are involved in signaling processes that involve phagocytosis of apoptotic cellular material and suppression of inflammatory activity as well as cytokine production [35].

The study by Guerreiro and colleagues investigated the association between heterozygous variants in the TREM2 gene and the risk of developing AD [36]. Exome and fullgenome sequencing revealed greater sequence variation in exon 2 of TREM 2 in AD patients compared with controls. The variant resulting in a $\mathrm{R} 47 \mathrm{H}$ substitution was identified to confer the greatest association with $\mathrm{AD}$, which was further confirmed through meta-analysis of statistics from genome-wide association studies as well as genotyping this variant in additional case and control samples. The study by Johnsson and colleagues focused on the search for TREM2 sequence variants that increased the risk of developing $\mathrm{AD}$. Whole-genome sequencing of samples obtained from Icelanders initially led to the identification of sequence variants that were likely to compromise protein function [37]. The same $\mathrm{R} 47 \mathrm{H}$ variant identified by Guerreiro and colleagues [36] was found to confer the greatest risk for developing $\mathrm{AD}$ in this study. The relationship between this mutation and AD risk was further confirmed through genotyping additional samples from other populations. Additionally, cognitive function in older mutation carriers but without AD diagnosis was investigated and compared with that of noncarriers, which revealed a more dramatic cognitive decline in carriers. Both studies suggest that the pathogenicity of the $\mathrm{R} 47 \mathrm{H}$ substitution with regards to AD may arise from accumulation of $\mathrm{A} \beta$ within the brain as a consequence of reduced phagocytic activity by receptor expressed on myeloid cells- 2 .

At least some of these genes associated with $\mathrm{AD}$ are part of the immune system, such as TREM2 and CR1, and are involved in $A \beta$ clearance. Clusterin also functions in $\mathrm{A} \beta$ clearance and variants in the $C L U$ gene have been linked to an increased AD risk, as previously described. Clusterin may have an as yet undiscovered role in immunity considering that its exact physiological function remains to be elucidated. The accumulation of $A \beta$ in brains of AD patients could at least be in part a result of the pathogenic variants identified in the TREM2, CR1, and $C L U$ genes since these may affect $\mathrm{A} \beta$ clearance by their protein products. Antibodies that gained access to the brain due to a compromised blood-brain barrier could then bind to the resulting $A \beta$ deposits, which may account for the presence of autoantibodies found in $A D$ patients. Alternatively, variants in the TREM2 and CR1, and perhaps $C L U$, genes may cause autoantibody 
production if their protein products differ drastically from the native version and as a result are not recognized by the immune system. Upon blood-brain barrier breakdown these autoantibodies could penetrate the brain, thus accounting for their presence in $\mathrm{AD}$ patients.

Evidence at the protein level is also suggestive of an AD-immune system connection. Work by the Nagele laboratory demonstrated the presence of brain-reactive autoantibodies in most human sera irrespective of age and disease status [38]. Furthermore, the antibodies were shown to possess the ability to penetrate the blood-brain barrier, which is generally compromised in AD patients, and once inside the brain the antibodies appeared to be involved in facilitation of intraneuronal $\mathrm{A} \beta 42$ deposition [39]. This led Nagele and coworkers to ask whether autoantibodies could be employed as diagnostic indicators of $\mathrm{AD}$ in a recent study [40]. To search broadly for such autoantibodies, commercially available protein microarrays containing approximately 9,500 unique human protein antigens were probed with sera from individuals with $\mathrm{AD}$ and from nondemented control subjects. The microarray data were subsequently analyzed by three different statistical algorithms, which classified mostly the same set of autoantibodies as significant biomarkers for $\mathrm{AD}$. The 10 most differentially expressed autoantibody biomarkers were then tested as diagnostic indicators of $\mathrm{AD}$ in separate serum samples and were shown to discriminate $\mathrm{AD}$ from control sera with reported sensitivities and specificities of $96 \%$ and $92 \%$, respectively. Additionally, these 10 biomarkers could distinguish $\mathrm{AD}$ from breast cancer and Parkinson's disease sera using the same microarray and algorithm approach.

Interestingly, none of the prospective $\mathrm{AD}$ autoantigens identified in this study are well-characterized proteins and none have been found to be involved in AD. Thus, if these markers do hold up in larger studies, their immunosignatures may provide a novel window into the biology of $\mathrm{AD}$ in the sense that it would be interesting to understand what the adaptive immune system 'thinks' is unusual about AD.

Another approach to mining the adaptive immune response for $\mathrm{AD}$ biomarkers was published recently by Johnston and coworkers [41]. They employed a similar approach, but used an array of peptides as probes. While peptide arrays have been employed extensively in experiments using sera from patients with autoimmune disease [42], this study differed from these earlier approaches in that it did not attempt to identify native peptide autoantigens, but rather sought to identify a biosignature by probing serum samples with an array of 10,000 20-residue peptides in which the residues at 17 of the positions were varied randomly [43]. In a preliminary study, they showed both in mouse models of $A D$ and in human patients that robust biosignatures indicative of $\mathrm{AD}$ could be visualized.
Few, if any, of these sequences in a random sequence library of 17 mers will correspond to epitopes that exist in nature. Thus, it is virtually impossible that any of the peptides identified in this study are exact mimics of $\mathrm{AD}$ autoantigens. Some of them may, however, share some homology with native linear autoantigenic peptides. Another possibility is that they do not bind anti-peptide antibodies at all but the peptides found to be interesting in this study simply happen to be ligands for antibodies that naturally bind other types of molecules. With this in mind, it is interesting to compare this study with one in which Chinnaiyin and colleagues screened a cDNAderived, phage-displayed peptide library against serum samples derived from patients with prostate cancer and healthy controls [44]. The investigators started with different goals. The Chinnaiyin group was attempting to identify native antigens while the Johnston group was not. Because of the way the phage-displayed library was made in the prostate cancer study, about five-sixths of the long peptides in the library were not represented in the human proteome. Yet the great majority of the peptide sequences found to capture autoantibodies that showed good prostate cancer specificity proved to be the abiological peptides. The Chinnaiyin study was probably therefore really a random peptide library screening exercise, akin to the Johnston AD study.

These papers provide clear evidence that molecules which cannot correspond exactly to native antigens are nonetheless capable of binding disease-associated antibodies with reasonable affinity. Indeed, this was already known from much earlier studies in which phage displayed peptides were selected as ligands against antibodies that naturally bind carbohydrates $[45,46]$. These AD and prostate cancer studies have shown that the same idea can productively be applied to screening against serum rather than simply individual mAbs.

A similar conclusion was reached in an even more dramatic fashion in a study from our laboratory that utilized arrays of completely unnatural molecules called peptoids as candidate ligands for AD-specific autoantibodies [47]. Peptoids are oligomers of $\mathrm{N}$-substituted glycines [48] (Figure 1). While they superficially appear to resemble peptides, the side chain protrudes from the $\mathrm{sp}^{2}$-hybridized nitrogen rather than the $\mathrm{sp}^{3}$-hybridized alpha carbon, as is the case for peptides. Moreover, the side-chain and main-chain nitrogens are derived from a primary amine during the so-called submonomer synthesis of peptoids [49]. Many of the side chains in the peptoids used in this study did not correspond to those found in natural proteins. Peptoids thus have a very different shape than peptides and cannot possibly mimic in any direct fashion the binding of a native antigen of any sort to an antibody. 


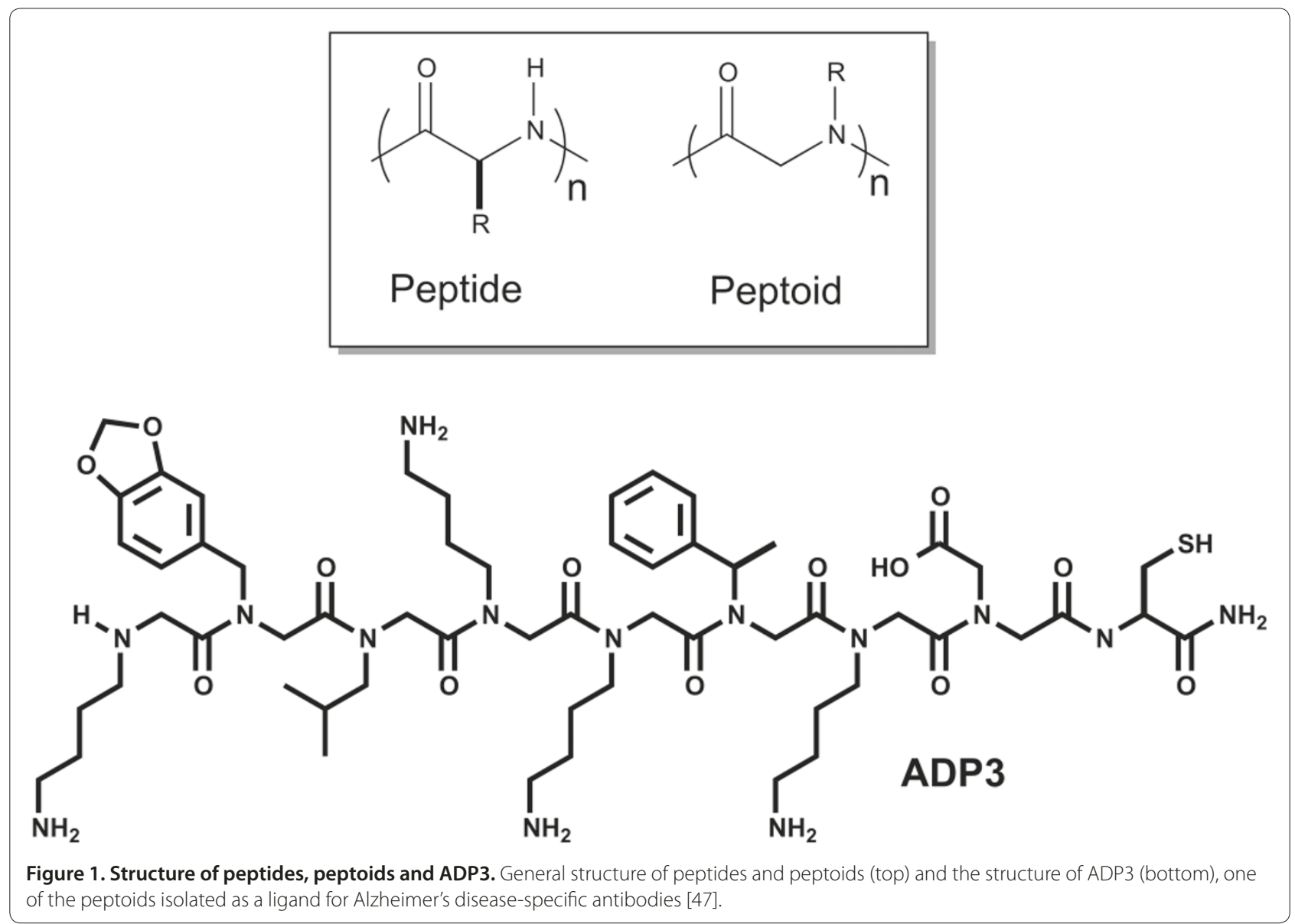

In this study, 4,608 octameric peptoids arrayed on chemically-modified glass slides were probed with serum samples obtained from six AD patients, six Parkinson's patients and six age-matched, cognitively normal individuals [50]. Three peptoids (Figure 1) were identified that bound much higher levels of IgG antibodies from all six of the AD patients and none of the 12 control patients. Experiments in which an AD serum sample was depleted of antibodies that recognized one of the peptoids revealed that two of three molecules recognized the same antibodies, while the other recognized distinct antibodies. Two distinct antibodies were thus implicated as $\mathrm{AD}$ biomarkers. Subsequent analysis of approximately 35 additional case and control serum samples not employed in the discovery set demonstrated that each of the peptoids individually provided excellent segregation of case and control samples. This is the first study to report that a single biomarker could accurately diagnose AD, at least in the context of this small sample set, rather than being forced to rely on a large panel of markers. This may indicate that searching chemical space outside that of peptides may be a more productive strategy for biomarker discovery, although much more work will have to be done to explore this issue rigorously.

Each of the three autoantibody-based studies described above are promising but preliminary $[40,41,47]$. Samples from $\mathrm{AD}$ patients, normal controls, and in some cases from patients with other diseases were analyzed, which led to the identification of distinct biomarker sets specific to each sample group and thus served as an initial proof of principle. As mentioned above, however, the utility of published biomarker candidates cannot truly be evaluated until large, blinded trials are undertaken. These must include samples taken from different cohorts and must be performed in more than one laboratory. Furthermore, additional studies should focus on the applicability of $\mathrm{AD}$-specific biomarker candidates to the distinction between samples from patients with $\mathrm{AD}$, mild cognitive impairment or with other types of dementia. This would be crucial for early and proper identification of $\mathrm{AD}$ patients, which would subsequently lead to improved treatment protocols. Hopefully, some of these autoantibody biomarkers will survive this scrutiny since, from a practical point of view, antibodies have many favorable characteristics as clinical biomarkers (see below). 


\section{Practical issues for development of a clinically viable} Alzheimer's disease test

Even when a plasma/serum biomarker is discovered that is sensitive and specific for $\mathrm{AD}$, this does not mean that a clinically viable test for that marker will be immediately available. While there are many practical issues in the conversion of any laboratory biomarker measurement into a robust clinical test, this will be especially true for a generally useful AD screening test.

As mentioned above, a screening test for presymptomatic AD would ideally be used on a very large scale. An argument could be made for testing everyone over the age of 50 every 3 to 5 years. The analytical platform employed to make these measurements will have to be extremely robust and relatively inexpensive. These requirements probably pose a challenge for tests that depend on a large number of markers, none of which are robust when considered individually, but when input into an algorithm can provide useful results in an ideal setting. Biological variance in a very large population will probably prove to be a greater problem because the number of markers one must depend upon increases. Variations in the way samples are collected and stored in the clinic are always a difficult issue for the measurement of serum proteins with limited stability, but the problem will be magnified for multimarker, algorithmic tests, particularly if the component markers have different halflives in a blood sample. The robust biochemical nature of antibodies [51] and the fact that the gross biochemical properties of one IgG are roughly the same as any other will to some degree alleviate this problem for tests based on these markers.

With respect to cost and test volume, it is noteworthy that all of the autoantibody-based tests discussed above $[40,41,47]$ were carried out using arrays of various types. These arrays are probably not clinically viable assay formats and it may not be completely straightforward to develop the probes from these surfaces to more conventional analytical platforms, such as ELISA plates or the like.

For example, we have found that the peptoids we reported perform far less well when attached to a plastic ELISA plate [52]. This decrease in performance is due to a much lower level of avidity-driven binding (two different surface-linked peptoids binding one IgG antibody through each of its two arms) than on the densely functionalized glass slide combined with a much higher level of nonspecific IgG binding to the peptoid-plastic surface as compared with the PEGylated glass. The combination of these two factors results in an unacceptable signal-to-noise ratio for assays carried out on simple ELISA plates. We are currently attempting to reformat the assay on a more favorable, although still practical, platform, as well as to identify higher affinity antibody ligands that are less dependent on surface effects to retain the bivalent IgG biomarkers. In any case, this provides an example of the nontrivial nature of adapting complex research laboratory-developed tests into robust clinical assays.

\section{Conclusion}

The pace of research in $\mathrm{AD}$ biomarker development has picked up markedly over the past 5 years. While our knowledge of AD pathways has not yet yielded a suitable marker, more unbiased approaches, relying on the availability of well-curated and standardized sample sets, have provided several interesting candidates. As discussed above, it will be important to validate these and future candidates extensively in multicenter trials. The discovery of effective markers should enable far more effective clinical trials of $\mathrm{AD}$ therapeutics to be carried out. While such efforts are proceeding, the diagnostic community could focus on perfecting diagnostic assays suitable for massive screening campaigns of middle-aged people. This is clearly one of the pre-eminent unsolved medical problems of our time.

This article is part of a series on Peripheral Biomarkers, edited by Douglas Galasko. Other articles in this series can be found at http://alzres.com/series/biomarkers

\section{Abbreviations}

$A \beta$, amyloid beta; $A D$, Alzheimer's disease; $A P O E$, gene encoding apolipoprotein $E_{;} C L U$, gene encoding clusterin; $C R 1$, gene encoding the complement component (3b/4b) receptor 1; ELISA, enzyme-linked immunoabsorbent assay; mAb, monoclonal antibody; SNP, single-nucleotide polymorphism; TREM2, gene encoding the triggering receptor expressed on myeloid cells-2.

\section{Competing interests}

TK has a substantial stake in a company developing an AD diagnostic test, Opko Health, Inc., and is a paid consultant. LFC declares that she has no competing interests.

\section{Acknowledgements}

The authors thank the National Institute of Diabetes and Digestive and Kidney Diseases for support by grant number DP3DK094309.

Published: 9 May 2013

\section{References}

1. Mayeux R, Stern Y: Epidemiology of Alzheimer disease. Cold Spring Harb Perspec Med 2012, 2. [Epub ahead of print]

2. Mayeux R, Schupf N: Blood-based biomarkers for Alzheimer's disease: plasma $A \beta 40$ and $A \beta 42$, and genetic variants. Neurobio/ Aging 2011, 32(Suppl 1):S10-S19.

3. Barnes DE, Yaffe $K$ : The projected effect of risk factor reduction on Alzheimer's disease prevalence. Lancet Neurol 2011, 10:819-828.

4. Bateman RJ, Xiong C, Benzinger TL, Fagan AM, Goate A, Fox NC, Marcus DS, Cairns NJ, Xie X, Blazey TM, Holtzman DM, Santacruz A, Buckles V, Oliver A, Moulder K, Aisen PS, Ghetti B, Klunk WE, McDade E, Martins RN, Masters CL, Mayeux R, Ringman JM, Rossor MN, Schofield PR, Sperling RA, Salloway S, Morris JC; Dominantly Inherited Alzheimer Network: Clinical and biomarker changes in dominantly inherited Alzheimer's disease. N Eng/ J Med 2012, 367:795-804

5. Selkoe DJ: Preventing Alzheimer's disease. Science 2012, 337:1488-1492.

6. O'Brien RJ, Wong PC: Amyloid precursor protein processing and 
Alzheimer's disease. Annu Rev Neurosci 2011, 34:185-204.

7. Ahmed M, Davis J, Aucoin D, Sato T, Ahuja S, Aimoto S, Elliott Jl, Van Nostrand WE, Smith SO: Structural conversion of neurotoxic amyloid- $\beta$ 1-42 oligomers to fibrils. Nat Struct Mol Biol 2010, 17:561-567.

8. Wilkinson K, El Khoury J: Microglial scavenger receptors and their roles in the pathogenesis of Alzheimer's disease. Int J Alzheimers Dis 2012, 2012:489456.

9. Hardy J, Selkoe DJ: The amyloid hypothesis of Alzheimer's disease: progress and problems on the road to therapeutics. Science 2002, 297:353-356

10. D'andrea MR, Nagele RG, Wang HY, Peterson PA, Lee DHS: Evidence that neurones accumulating amyloid can undergo lysis to form amyloid plaques in Alzheimer's disease. Histopathology 2001, 38:120-134.

11. D'andrea MR, Lee DHS, Wang HY, Nagele RG: Targeting intracellular A $\beta 42$ for Alzheimer's disease drug discovery. Drug Dev Res 2002, 56:194-200.

12. Nagele RG, D'Andrea MR, Anderson WJ, Wang HY: Intracellular accumulation of beta-amyloid(1-42) in neurons is facilitated by the alpha 7 nicotinic acetylcholine receptor in Alzheimer's disease. Neuroscience 2002, 110:199-211.

13. Clifford PM, Zarrabi S, Siu G, Kinsler KJ, Kosciuk MC, Venkataraman V, D'Andrea $M R$, Dinsmore S, Nagele RG: A $\beta$ peptides can enter the brain through a defective blood-brain barrier and bind selectively to neurons. Brain Res 2007, 1142:223-236

14. Patel AN, Jhamandas JH: Neuronal receptors as targets for the action of amyloid-beta protein (A $\beta$ ) in the brain. Expert Rev Mol Med 2012, 14:e2.

15. Salminen A, Ojala J, Kauppinen A, Kaarniranta K, Suuronen T: Inflammation in Alzheimer's disease: amyloid- $\beta$ oligomers trigger innate immunity defence via pattern recognition receptors. Prog Neurobiol 2009, 87:181-194.

16. McLarnon JG: Microglial chemotactic signaling factors in Alzheimer's disease. Am J Neurodegener Dis 2012, 1:199-204.

17. Blennow K, Zetterberg H, Fagan AM: Fluid biomarkers in Alzheimer disease. Cold Spring Harb Perspec Med 2012, 2:a006221.

18. Jones SE, Jomary C: Clusterin. Int J Biochem Cell Biol 2002, 34:427-431.

19. Wu ZC, Yu JT, Li Y, Tan L: Clusterin in Alzheimer's disease. Adv Clin Chem 2012, 56:155-173.

20. Dabbs RA, Wyatt AR, Yerbury JJ, Ecroyd H, Wilson MR: Extracellular chaperones. Top Curr Chem 2013, 328:241-268.

21. Yerbury JJ, Poon S, Meehan S, Thompson B, Kumita JR, Dobson CM, Wilson MR: The extracellular chaperone clusterin influences amyloid formation and toxicity by interacting with prefibrillar structures. FASEB J 2007 , 21:2312-2322.

22. Yu JT, $\operatorname{Tan} \mathrm{L}:$ The role of clusterin in Alzheimer's disease: pathways, pathogenesis, and therapy. Mol Neurobiol 2012, 45:314-326.

23. Calero M, Rostagno A, Matsubara E, Zlokovic B, Frangione B, Ghiso J: Apolipoprotein J (clusterin) and Alzheimer's disease. Microsc Res Tech 2000, 50:305-315.

24. Harold D, Abraham R, Hollingworth P, Sims R, Gerrish A, Hamshere ML, Pahwa JS, Moskvina V, Dowzell K, Williams A, Jones N, Thomas C, Stretton A, Morgan AR, Lovestone S, Powell J, Proitsi P, Lupton MK, Brayne C, Rubinsztein DC, Gill M, Lawlor B, Lynch A, Morgan K, Brown KS, Passmore PA, Craig D, McGuinness B, Todd S, Holmes C, Mann D, et al:: Genome-wide association study identifies variants at CLU and PICALM associated with Alzheimer's disease. Nat Genet 2009, 41:1088-1093.

25. Lambert JC, Heath S, Even G, Campion D, Sleegers K, Hiltunen M, Combarros O, Zelenika D, Bullido MJ, Tavernier B, Letenneur L, Bettens K, Berr C, Pasquier F, Fiévet N, Barberger-Gateau P, Engelborghs S, De Deyn P, Mateo I, Franck A, Helisalmi S, Porcellini E, Hanon O; European Alzheimer's Disease Initiative Investigators, de Pancorbo MM, Lendon C, Dufouil C, Jaillard C, Leveillard T, Alvarez V, et al:: Genome-wide association study identifies variants at CLU and CR1 associated with Alzheimer's disease. Nat Genet 2009, 41:1094-1099.

26. Strittmatter WJ, Saunders AM, Schmechel D, Pericak-Vance M, Enghild J, Salvesen GS, Roses AD: Apolipoprotein E: high-avidity binding to betaamyloid and increased frequency of type 4 allele in late-onset familial Alzheimer disease. Proc Natl Acad SciU S A 1993, 90:1977-1981.

27. Thambisetty M, Simmons A, Velayudhan L, Hye A, Campbell J, Zhang Y, Wahlund LO, Westman E, Kinsey A, Guntert A, Proitsi P, Powell J, Causevic M, Killick R, Lunnon K, Lynham S, Broadstock M, Choudhry F, Howlett DR, Williams RJ, Sharp SI, Mitchelmore C, Tunnard C, Leung R, Foy C, O'Brien D, Breen G, Furney SJ, Ward M, Kloszewska I, et al:: Association of plasma clusterin concentration with severity, pathology, and progression in Alzheimer disease. Arch Gen Psychiatry 2010, 67:739-748.
28. Schrijvers EM, Koudstaal PJ, Hofman A, Breteler MM: Plasma clusterin and the risk of Alzheimer disease. JAMA 2011, 305:1322-1326.

29. Silajdzic E, Minthon L, Bjorkqvist M, Hansson O: No diagnostic value of plasma clusterin in Alzheimer's disease. PloS One 2012, 7:e50237.

30. Anderson NL, Ansderson NG: The human plasma proteome: history, character and diagnostic prospects. Mol Cell Proteomics 2002, 1:845-867.

31. Ray S, Britschgi M, Herbert C, Takeda-Uchimura Y, Boxer A, Blennow K, Friedman LF, Galasko DR, Jutel M, Karydas A, Kaye JA, Leszek J, Miller BL, Minthon L, Quinn JF, Rabinovici GD, Robinson WH, Sabbagh MN, So YT, Sparks DL, Tabaton M, Tinklenberg J, Yesavage JA, Tibshirani R, Wyss-Coray T: Classification and prediction of clinical Alzheimer's diagnosis based on plasma signaling proteins. Nat Med 2007, 13:1359-1362.

32. Hu WT, Holtzman DM, Fagan AM, Shaw LM, Perrin R, Arnold SE, Grossman M, Xiong C, Craig-Schapiro R, Clark CM, Pickering E, Kuhn M, Chen Y, Van Deerlin VM, McCluskey L, Elman L, Karlawish J, Chen-Plotkin A, Hurtig HI, Siderowf A, Swenson F, Lee VM, Morris JC, Trojanowski JQ, Soares H; Alzheimer's Disease Neuroimaging Initiative: Plasma multianalyte profiling in mild cognitive impairment and Alzheimer disease. Neurology 2012, 79:897-905.

33. Bjorkqvist M, Ohlsson M, Minthon L, Hansson O: Evaluation of a previously suggested plasma biomarker panel to identify Alzheimer's disease. PLoS One 2012, 7:e29868.

34. Soares HD, Chen Y, Sabbagh M, Rohrer A, Schrijvers E, Breteler M: Identifying early markers of Alzheimer's disease using quantitative multiplex proteomic immunoassay panels. Ann NY Acad Sci 2009, 1180:56-67.

35. Neumann $\mathrm{H}$, Takahashi K: Essential role of the microglial triggering receptor expressed on myeloid cells-2 (TREM2) for central nervous tissue immune homeostasis. J Neuroimmunol 2007, 184:92-99.

36. Guerreiro R, Wojtas A, Bras J, Carrasquillo M, Rogaeva E, Majounie E, Cruchaga C, Sassi C, Kauwe JS, Younkin S, Hazrati L, Collinge J, Pocock J, Lashley T, Williams J, Lambert JC, Amouyel P, Goate A, Rademakers R, Morgan K, Powell J, St George-Hyslop P, Singleton A, Hardy J; Alzheimer Genetic Analysis Group: TREM2 variants in Alzheimer's disease. N Eng/ J Med 2013, 368:117-127.

37. Jonsson T, Stefansson H, Steinberg S, Jonsdottir I, Jonsson PV, Snaedal J, Bjornsson S, Huttenlocher J, Levey Al, Lah JJ, Rujescu D, Hampel H, Giegling I, Andreassen OA, Engedal K, Ulstein I, Djurovic S, Ibrahim-Verbaas C, Hofman A, Ikram MA, van Duijn CM, Thorsteinsdottir U, Kong A, Stefansson K: Variant of TREM2 associated with the risk of Alzheimer's disease. N Engl J Med 2013 368:107-116

38. Levin EC, Acharya NK, Han M, Zavareh SB, Sedeyn JC, Venkataraman V, Nagele RG: Brain-reactive autoantibodies are nearly ubiquitous in human sera and may be linked to pathology in the context of blood-brain barrier breakdown. Brain Res 2010, 1345:221-232.

39. Nagele RG, Clifford PM, Siu G, Levin EC, Acharya NK, Han M, Kosciuk MC, Venkataraman V, Zavareh S, Zarrabi S Kinsler K, Thaker NG, Nagele EP, Dash J, Wang HY, Levitas A: Brain-reactive autoantibodies prevalent in human sera increase intraneuronal amyloid-beta(1-42) deposition. J Alzheimers Dis 2011, 25:605-622.

40. Nagele E, Han M, Demarshall C, Belinka B, Nagele R: Diagnosis of Alzheimer's disease based on disease-specific autoantibody profiles in human sera. PLoS One 2011, 6:e23112.

41. Restrepo L, Stafford P, Magee DM, Johnston SA: Application of immunosignatures to the assessment of Alzheimer's disease. Ann Neurol 2011, 70:286-295.

42. Robinson WH, DiGennaro C, Hueber W, Haab B, Kamachi M, Dean E, Fournel S, Fong D, Genovese MC, de Vegvar H, Skriner K, Hirschberg DL, Morris RL, Muller S, Pruijn GJ, van Venrooij WJ, Smolen JS, Brown PO, Steinman L, Utz PJ: Antigen arrays for multiplex characterization of autoantibody responses. Nat Med 2002, 8:295-301.

43. Halperin RF, Stafford P, Johnston SA: Exploring antibody recognition of sequence space through random-sequence peptide microarrays. Mol Cell Proteomics 2011, 10:M110 000786.

44. Wang X, Yu J-Q, Sreekumar A, Varambally S, Shen R, Giachero D, Mehra R, Montie JE, Pienta KJ, Sanda MG, Kantoff PW, Rubin MA, Wei JT, Ghosh D, Chinnaiyan AM: Autoantibody signatures in prostate cancer. NEngl J Med 2005, 355:16-27.

45. Harris SL, Craig L, Mehroke JS, Rashed M, Zwick MB, Kenar K, Toone EJ, Greenspan N, Auzanneau FI, Marino-Albernas JR, Pinto BM, Scott JK: Exploring the basis of peptide-carbohydrate crossreactivity: evidence for discrimination by peptides between closely related anti-carbohydrate antibodies. Proc Natl Acad Sci U S A 1997, 94:2454-2459.

46. Phalipon A, Folgori A, Arondel J, Sgaramella G, Fortugno P, Cortese R, 
Sansonetti PJ, Felici F: Induction of anti-carbohydrate antibodies by phage library-selected peptide mimics. Eur J Immunol 1997, 27:2620-2625.

47. Reddy MM, Wilson R, Wilson J, Connell S, Gocke A, Hynan L, German D, Kodadek T: Identification of candidate lgG biomarkers for Alzheimer's disease via combinatorial library screening. Cell 2011, 144:132-142.

48. Simon RJ, Kania RS, Zuckermann RN, Huebner VD, Jewell DA, Banville $S, N g$ S, Wang L, Rosenberg S, Marlowe CK, et al:: Peptoids: a modular approach to drug discovery. Proc Natl Acad Sci U S A 1992, 89:9367-9371.

49. Figliozzi GM, Goldsmith R, Ng SC, Banville SC, Zuckermann RN: Synthesis of N-substituted glycine peptoid libraries. Methods Enzymol 1996, 267:437-447.

50. Reddy MM, KodadekT: Protein 'fingerprinting' in complex mixtures with peptoid microarrays. Proc Natl Acad Sci U S A 2005, 102:12672-12677.
51. Chase BA, Johnston SA, Legutki JB: Evaluation of biological sample preparation for immunosignature-based diagnostics. Clin Vaccine Immunol 2012, 19:352-358.

52. Kodadek T, Moola R, Schilke, J, Wilson R, Wilson, J: Candidate serum IGG biomarkers of Alzheimer's disease. Alzheimer's Disease \& Dementia: The Journal of the Alzheimer's Association 2012, 8 (Suppl):P79.

\section{doi:10.1186/alzrt172}

Cite this article as: Clark LF, Kodadek T: Advances in blood-based protein biomarkers for Alzheimer's disease. Alzheimer's Research \& Therapy 2013, 5:18. 